\title{
UTERINE PROTEINS IN THE MARSUPIAL, DIDELPHIS MARSUPIALIS VIRGINIANA, DURING GESTATION
}

\author{
MARILYN B. RENFREE* \\ Department of Zoology, University of Tennessee, Knoxville, \\ Tennessee 37916, U.S.A.
}

(Received 8th fuly 1974)

The North American opossum, Didelphis marsupialis virginiana, is a polyovular, polyoestrous marsupial. The gestation period of 13 days is the same length as the luteal phase of the cycle (Hartman, 1923, 1925); the next pro-oestrous phase and ovulation are suppressed by the presence of sucking young in the pouch. During the breeding season, removal or loss of the young results in resumption of follicular growth and oestrous behaviour is evident 3 to 7 days later (Hartman, 1923; Renfree, 1974). After ovulation, the two uteri increase greatly in size and turgidity, due to an accumulation of fluid in the hypertrophied mucosa and the development of a rich supply of capillaries and venules (Hartman, 1923). Ciliated surface cells are involved in the deposition of much ground substance in the stroma, and the secretory cells of the glands have abundant smooth and rough endoplasmic reticulum as well as expanded Golgi apparatus: in pregnancy, both transport and secretory cells are prominent and are presumed to supply the fetus with haemotrophe and histotrophe (Padykula \& Taylor, 1971). The present communication describes the protein components of this embryotrophe and the weight changes in the endometrium throughout gestation. Three of the ovariectomized females that carried their fetuses to term during a previous study (Renfree, 1974) were included for comparison.

Opossums were collected and housed as already described (Renfree, 1974). Fetal fluids from three pregnant opossums, and the endometrium from twentysix uterine horns of twenty animals were collected by methods used previously for the tammar wallaby, Macropus eugenii (Renfree, 1973a, b). The endometrium and uterine exudates were also collected from the uteri of five nonpregnant females at Days 2, 4, 5 and 8 after oestrus. Maternal plasma was collected at laparotomy or autopsy by cardiac puncture, and all samples were stored at $-20^{\circ} \mathrm{C}$ until assayed. The protein concentration of the fluids was determined by the method of Lowry, Rosebrough, Farr \& Randall (1951), using bovine serum albumin as standard. Acrylamide electrophoresis was carried out on all samples of each of the three systems; on disc gels (Davis, 1964), with application of $5 \mu \mathrm{l}$ uterine exudate and $2.5 \mu \mathrm{l}$ serum; gradient gels (Gradipore: Margolis \& Kenrick, 1968) with $2.5 \mu$ l exudate and serum; and slab gels (Reid \& Bieleski, 1968) with $5 \mu$ l exudate and $2.5 \mu \mathrm{l}$ serum.

* Present address: School of Environmental and Life Sciences, Murdoch University, Murdoch, Western Australia 6153. 
In lactating animals, the uteri were quiescent and the endometrial wet weight was less than $0.5 \mathrm{~g}$. During gestation, both uteri became gravid and the endometrial weight of each increased to over $10 \mathrm{~g}$ by Day 9 , but remained high for only a few days (Text-fig. 1). Measurements at Day 12 were very variable. There were no differences in weight between the samples from the five cyclic non-pregnant animals and from the three animals ovariectomized on Day 6, 8 or 10 and killed on Day 12 and those from the uteri of normal pregnant opossums.

The exudates collected from twenty-six uteri from Days 3 to 12 contained $116.7 \pm 24.9 \mathrm{mg}$ protein $/ \mathrm{ml}$. This value is only slightly higher than the mean value for normal adult serum from sixty-seven animals $(93.6 \pm 21.4 \mathrm{mg}$ protein $/ \mathrm{ml}$ ). The volumes of the samples from the lactating and Day-2 pregnant

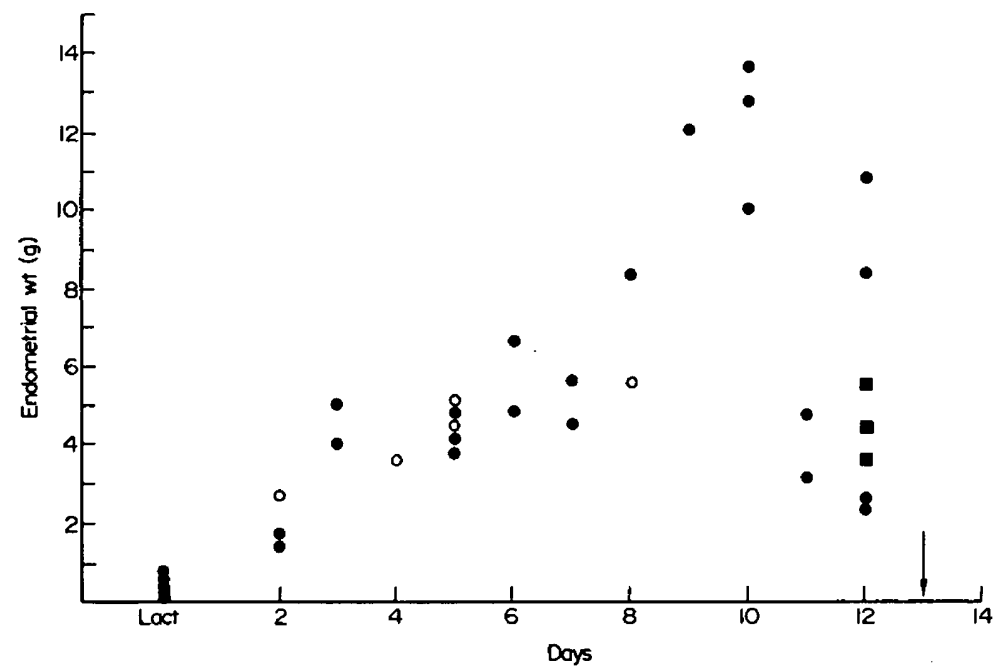

Text-rig. 1. The weight of opossum endometrium. ๑, Pregnant; $\bigcirc$, non-pregnant, after oestrus; $\square$, ovariectomized; Lact, uteri from lactating females. Arrow shows time of birth.

animals were not sufficient for protein determination, but disc electrophoresis indicated the paucity of protein in these early samples (Plate 1). The secretion was well established by Day 3, and the concentration and pattern of the proteins remained unchanged to the end of gestation. The protein patterns and concentrations in uterine exudates from the non-pregnant animals and the ovariectomized females were identical to those of animals from Day 3 to Day 12 of normal pregnancy. On disc electrophoresis, the only apparent difference from serum was the presence of prealbumins in the uterine exudates.

With gradient electrophoresis, six prealbumins were resolved, but none appeared in serum. On slab gels, only five of the prealbumins were easily visible, and one was common to serum (Plate 2). One or two $\beta$-globulins, apparently absent from serum, were always observed in the uterine exudates. From the electrophoretic mobility, these bands are most likely to be free haemoglobin or haptoglobin proteins (see Davis \& Jurgelsky, 1973), since the 
PLATE 1

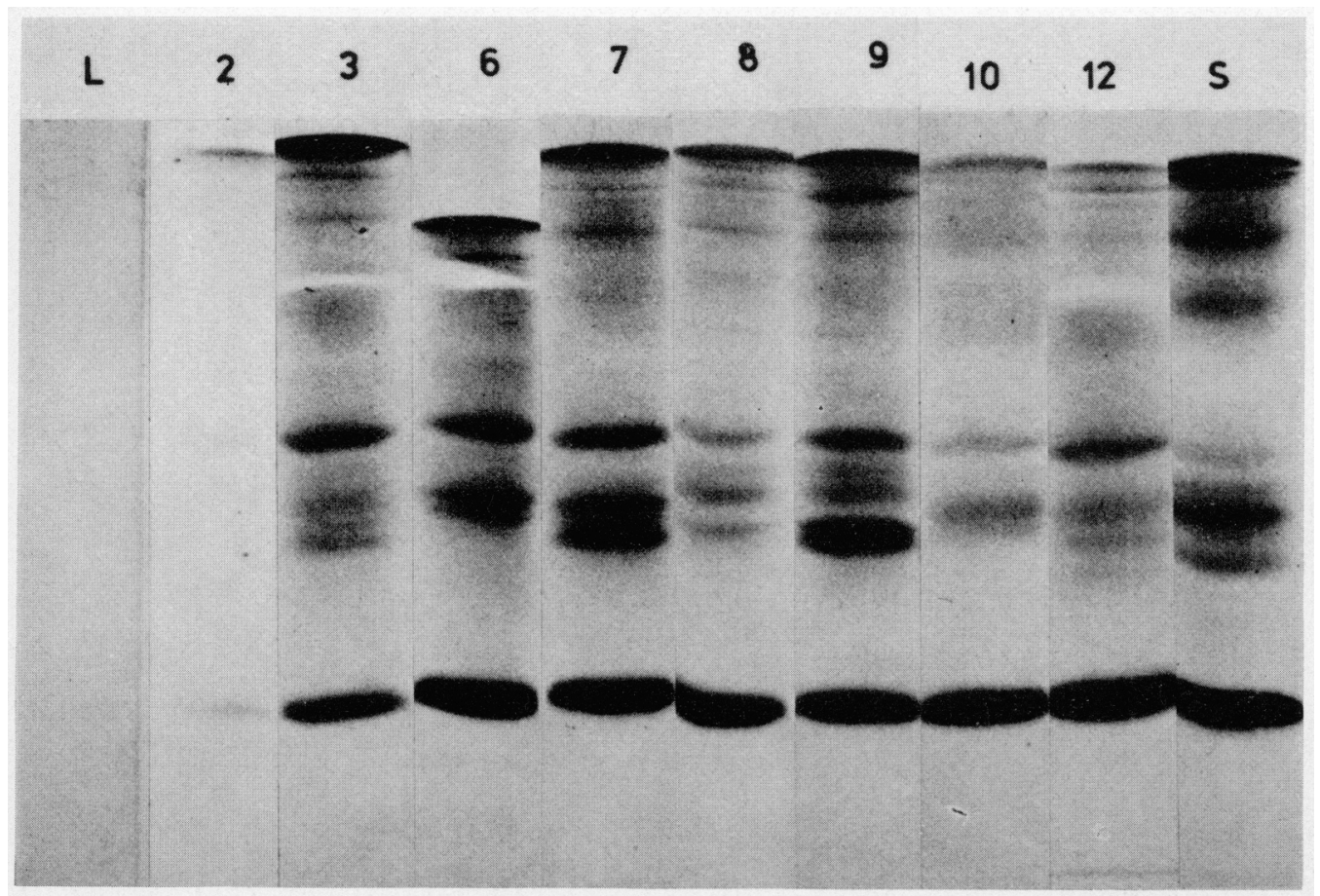

Disc electrophoretic patterns of opossum uterine exudates. L, lactating; 2 to 12 , days of gestation; S, serum. Lactating and Day-2 samples have negligible amounts of protein. At Day 3, protein amounts have increased and those of all samples to full-term closely resemble serum patterns. A single prealbumin can be seen in some of the exudate gels. 
PLATE 2

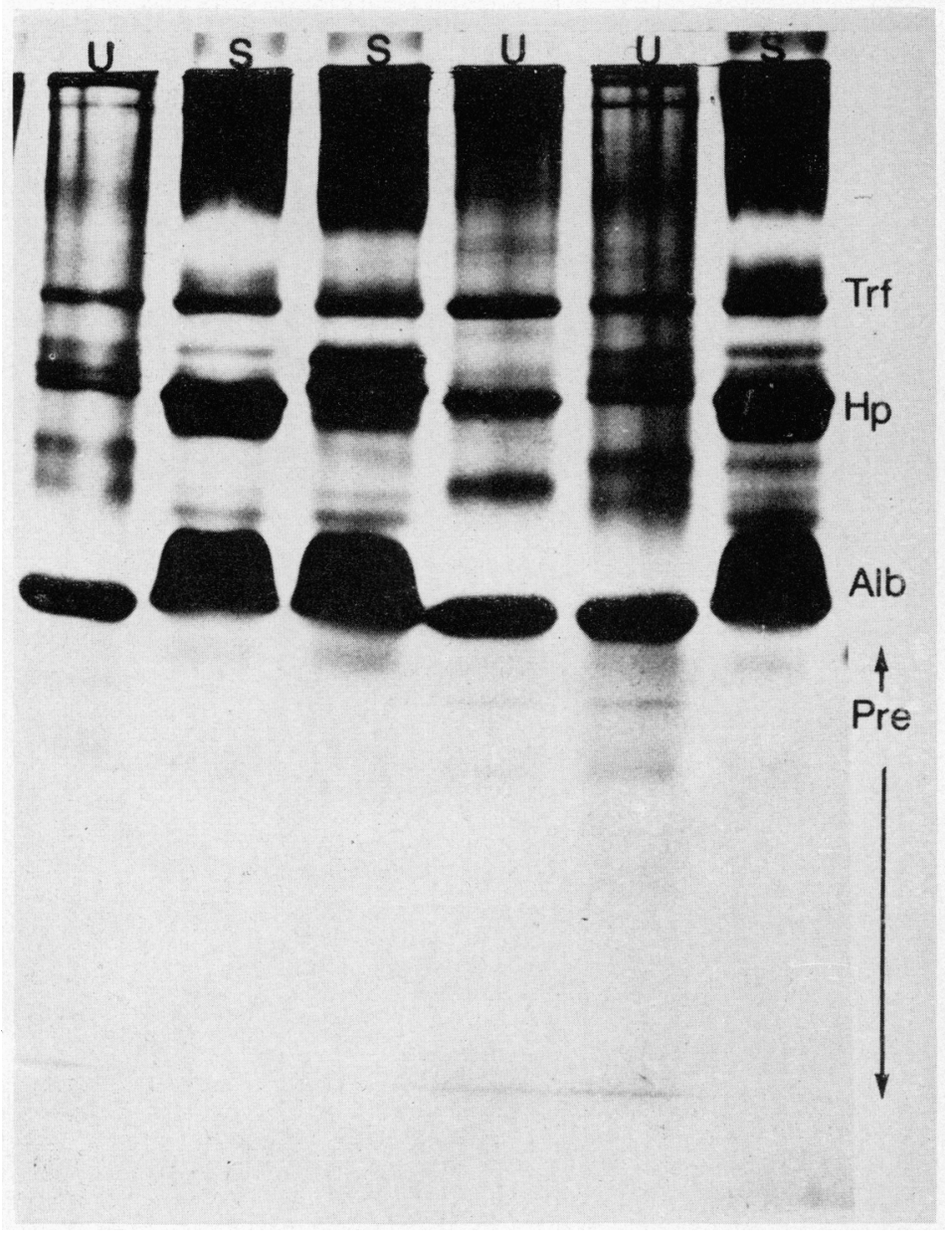

Slab gel electrophoresis of opossum uterine exudates $(\mathbf{U})$ and serum $(\mathbf{S})$. Trf, transferrins; $\mathrm{Hp}$, haptoglobins; Alb, albumin; Pre, prealbumins. Note the $\beta$-globulins between $\mathrm{Hp}$ and $\mathrm{Alb}$ in the uterine exudates. Several prealbumins are evident in the exudates which are apparently absent from serum. Albumin mobility of exudates is always faster than serum albumin. The samples were from Day 12 of gestation. 
exudates were always greatly haemolysed. One consistent feature of all the opossum exudates was the increased electrophoretic mobility of the albumin when compared to serum albumin. A similar increase in albumin mobility has been observed in uterine fluids of the rabbit (Cowan \& Daniel, 1972) and the wallaby (Renfree, 1973a).

The yolk-sac fluids and the allantoic fluids contained few protein components, the major bands being prealbumin and albumin: some very faint bands were visible in the $\alpha$ - and $\beta$-globulin regions of the gel. Yolk-sac fluid changed from colourless to a characteristic yellow colour at Day 11 about 1 day after implantation and the loss of the maternally derived shell membrane.

In the opossum, the endometrial weight and protein concentration correspond exactly to the development of the corpus luteum and the luteal phase. In the tammar wallaby, however, gestation continues beyond the decline of the corpus luteum (Renfree \& Tyndale-Biscoe, 1973). Although the uterus of the opossum is actively secreting fluid (Padykula \& Taylor, 1971), the secretion consists of fewer uterine-specific proteins than have been found in the tammar wallaby (Renfree, 1973a), although greater endometrial development occurs and a larger volume of fluid accumulates. The uteri of pregnant opossums produce the same secretion and show the same degree of endometrial proliferation as do those of non-pregnant, cyclic animals, but the non-gravid uterus of the tammar wallaby remains less well developed and produces a different secretion from that of the gravid uterus (Renfree \& Tyndale-Biscoe, 1973).

The increase in endometrial weight and the quantity of secretion from the uterus of the phalangerid, Trichosurus vulpecula, coincide with the luteal phase, as they do in the opossum, and the secretion more closely resembles serum in its protein components than does that of the tammar wallaby (G. H. TyndaleBiscoe and N. J. Cantrill, personal communication). Since $T$. vulpecula is a monovular species, this similarity between the exudates of the gravid and nongravid uteri, and the similarity of the uterine endometrium at the cellular and subcellular levels (Shorey \& Hughes, 1973), suggests, as do the comparisons between non-pregnant and pregnant opossums, that in the Didelphidae and Phalangeridae there is no feto-placental effect on the endometrium such as has been proposed for the Macropodidae (Renfree, 1972; Tyndale-Biscoe, Hearn \& Renfree, 1974). Gestation is instead a very much more rapid process in a uterine environment well supplied with large volumes of a protein-rich fluid.

I thank Dr J. C. Daniel, Jr for his interest and for the provision of facilities. I also thank Dr D. A. T. New for the gift of four of the opossum uteri used in this study.

\section{REFERENCES}

Cowan, B. D. \& Daniet, J. C. (1972) Difference in electrophoretic mobility between albumin of rabbit uterine fluid and serum albumin. Fert. Steril. 23, 81-84.

Davis, B. J. (1964) Disc electrophoresis. II. Method and application to human serum proteins. Ann. N.r. Acad. Sci. 121, 404-427.

Davis, P. J. \& JURGeLsky, W. (1973) Thyroid hormone-binding in opossum serum: evidence for polymorphism and relationship to haptoglobin polymorphism. Endocrinology, 92, 822-832. 
Martman, C. G. (1923) The oestrus cycle in the opossum. Am. 7. Anat. 32, 353-421.

Hartman, G. G. (1925) Hysterectomy and the oestrous cycle in the opossum. Am. F. Anat. 35, 25-29. Lowry, O. H., Rosebrough, N.J., FarR, A. L., \& Randall, R. J. (1951) Protein measurement with the Folin phenol reagent. F. biol. Chem. 193, 265-275.

Margolis, J. \& Kenrick, K. G. (1968) Polyacrylamide-gel electrophoresis in a continuous molecular sieve gradient. Analyt. Biochem. 25, 347-362.

Padykula, H. A. \& Taylor, J. M. (1971) Ultrastructural differentiation of the endometrium of the opossum (Didelphis marsupialis virginiana) during pregnancy. Anat. Rec. 169, 394.

Reid, M. S. \& Bieleski, R. L. (1968) A simple apparatus for vertical flat-sheet polyacrylamide gel electrophoresis. Analyt. Biochem. 22, 374-381.

Renfree, M. B. (1972) Influence of the embryo on the marsupial uterus. Nature, Lond. 240, 475-477.

Renfree, M. B. (1973a) Proteins in the uterine secretions of the marsupial, Macropus eugenii. Devl Biol. 32, 41-49.

Renfree, M. B. (1973b) The composition of fetal fluids in the marsupial, Macropus eugeni. Devl Biol. 33, 62-79.

Renfree, M. B. (1974) Ovariectomy during gestation in the American opossum, Didelphis marsupialis virginiana. 7. Reprod. Fert. 39, 127-130.

Renfree, M. B. \& Tyndale-Biscor, C. H. (1973) Intra-uterine development after diapause in the marsupial, Macropus eugenii. Devl Biol. 32, 28.

Shorey, C. D. \& Hughes, R. L. (1973) Cyclical changes in the uterine endometrium and peripheral plasma concentrations of progesterone in the marsupial Trichosurus vulpecula. Aust. 7. Zool. 21, 1-19.

Tyndale-Biscoe, C. H., Hearn, J. P. \& Renfree, M. B. (1974) Control of reproduction in macropod marsupials. F. Endocr. (in press). 